J. Gen. Appl. Microbiol. Vol. 12, No. 3, 1966

\title{
AN AFLATOXIN STRAIN ATCC-15517
}

\author{
HIDEYA MURAKAMI, KYÔKO ÔWAKI and SUMIO TAKASE \\ Research Institute of Brewing \\ Tokyo \\ Received March 9, 1966
}

It is well known that some strains of the genus Aspergillus produce aflatoxin and strain ATCC-15517 is one of the first known aflatoxin strains obtained by Mateles (1) from the Tropical Products Institute in London and $A$. flavus Link ex. Fries (2) is also the earliest known strain to produce aflatoxin. It seems that the majority of aflatoxin strains, so far as is known, belongs to $A$. flavus and some of them to A. parasiticus.

Production of alcoholic beverages and seasonings in Japan has been done mainly by using the fungus Aspergillus for over thousand years, and innumerable kinds of strains are known. Since the worldwide occurrence of aflatoxin strains was known, it became one of the most urgent and important problems in Japan where these fungi are being used industrially in this country, although some of strains belonging to A. flavus or A. parasiticus have rarely been found in some kinds of koji (3).

Taxonomic studies on Aspergillus were presented by many workers, such as THOM and CHuRch (4), THOM and RAPER (5), and RAPER and FENNELL (6) on various species of groups, and SAKAGUCHI and YAMADA ( 7 ), and OHARA (8) and NeHiRA (9) chiefly on industrial strains in Japan, but no taxonomic studies have hitherto been reported on the aflatoxin strains. Therefore, we examined the strain ATCC-15517 as a representative aflatoxin strain, both from morphological and physiological points, by comparing with about 200 strains of industrial yellow green-spored Aspergilli, in which were included mainly $A$. oryzae and its varieties together with some other strains such as 12 strains of $A$. flavus, 24 strains of $A$. parasiticus, and 3 strains of $A$. soyae, collected and stocked at the Research Institute of Brewing since 1904, or isolated by the authors from various industrial materials during 1953 to 1962, or given from many factories and laboratories in Japan during 1958 to 1965 . The strain ATCC-15517 was received from the National Institute of Health, Tokyo, in 1965.

\section{RESULTS AND DISCUSSION}

\section{Taxonomy}

Aspergillus parasiticus Speare var. globosus Murakami, nov. var.

A specie differt late crescentibus colonies, radiatis, columnaribus capitulis 


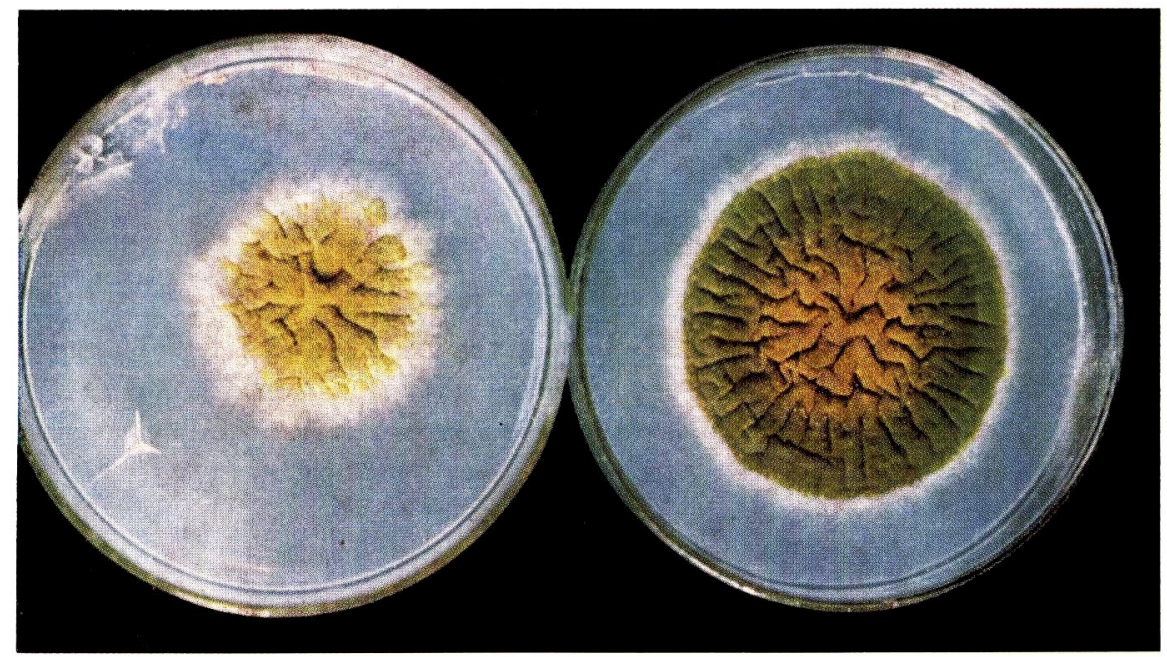

Fig. 1. Colonies of the strain ATCC-15517 on Czapek solution-agar incubated for 7 days in duplicate at $24^{\circ}$ (left) and $34^{\circ}$ (right).

conidicis, vesiculosis globosis penitus, $30-40 \times 32-42 \mu$, et globosis asperulis conidicis, plerumque $4-5 \mu$ in diameter (ATCC-15517, typus).

Aspergillus parasiticus Speare var. globosus Murakami, nov. var.

Colonies on Czapek solution-agar incubated for 7 days were velvety, strongly furrowed at both surface and reverse, yellowish yellow green, 40 to $50 \mathrm{~mm}$ in diameter at $24^{\circ}$ incubation, and dark green with central shades of yellowish brown, 60 to $70 \mathrm{~mm}$ in diameter at $34^{\circ}$ incubation, as shown in Fig. 1. Such morphorogical characteristics were not found in any other fungi.

Slant on Czapek solution-agar incubated at $30^{\circ}$ began to form conidia in 25 to $30 \mathrm{hr}$; passing through yellow, 4 to 6 hours after conidia formation, into deep yellow green after 7 days, and keeping very dark greenish gray (Munsell notation 5GY-3/2) after over 30 days. Very short stalked, strongly wrinkled transversely, reddish brown pigment forming gradually in agar, sometimes purplish black-colored particles (not sclerotia) scattered at the bottom edge of the tube. Only two strains among the other fungi showed the same color as these in slants, but they were different in other appearances.

Conidiophores 300 to $600 \mu$ long by 6 to $12 \mu$ in diameter with prominently roughened walls. Conidial heads radiate as broom 150 to $200 \mu$ in diameter. Conidiophores broadening upward and acutely enlarging into globose vesicles 


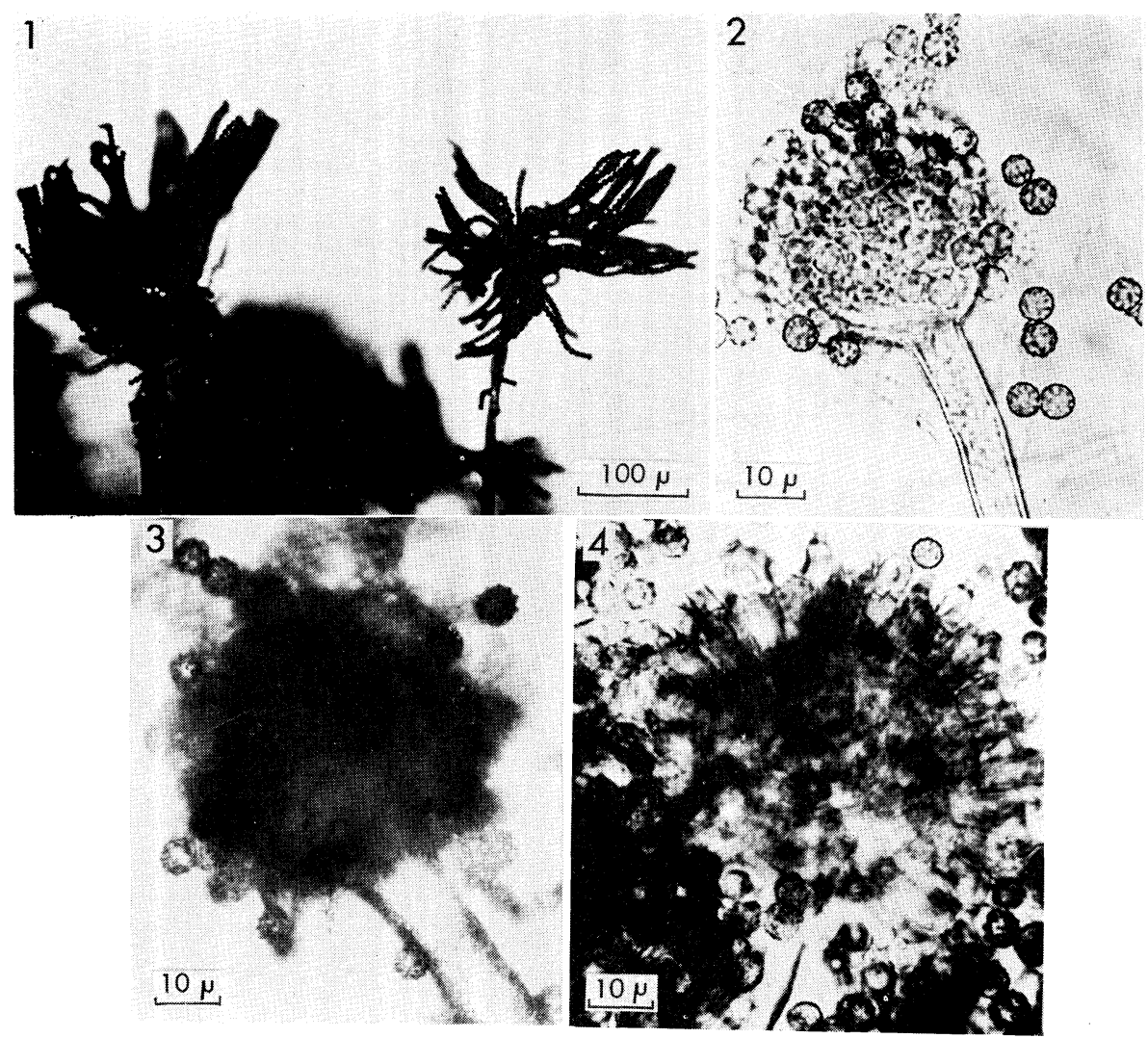

Fig. 2. Microstructure of the strain ATCC-15517.

1. Conidial heads

2. Young vesicle

3. Old vesicle

4. Vesicle grown on koji-extract agar

30 to $40 \mu$ by 32 to $42 \mu$ in diameter as shown in Fig. 2 . Sterigmata usually in two series, sometimes in one series, tending toward increasing two series by exposure to ultraviolet ray, primary 8 to $10 \mu$ by 4 to $7 \mu$, secondary 5 to $7 \mu$ by 3 to $4 \mu$.

Conidia with markedly roughened walls, globose 4 to $5 \mu$ in diameter. Electron micrograms of conidial walls of A. flavus, A. oryzae, A. soyae, A. parasiticus, and this fungus are shown in Fig. 3.

The type specimen and living culture derived from the type are deposited in the herbarium of American Type Culture Collection (ATCC-15517; Type).

This variety is very close to $A$. parasiticus but differs from the species in having roughened conidia and entirely globose vesicles. The infraspecific 

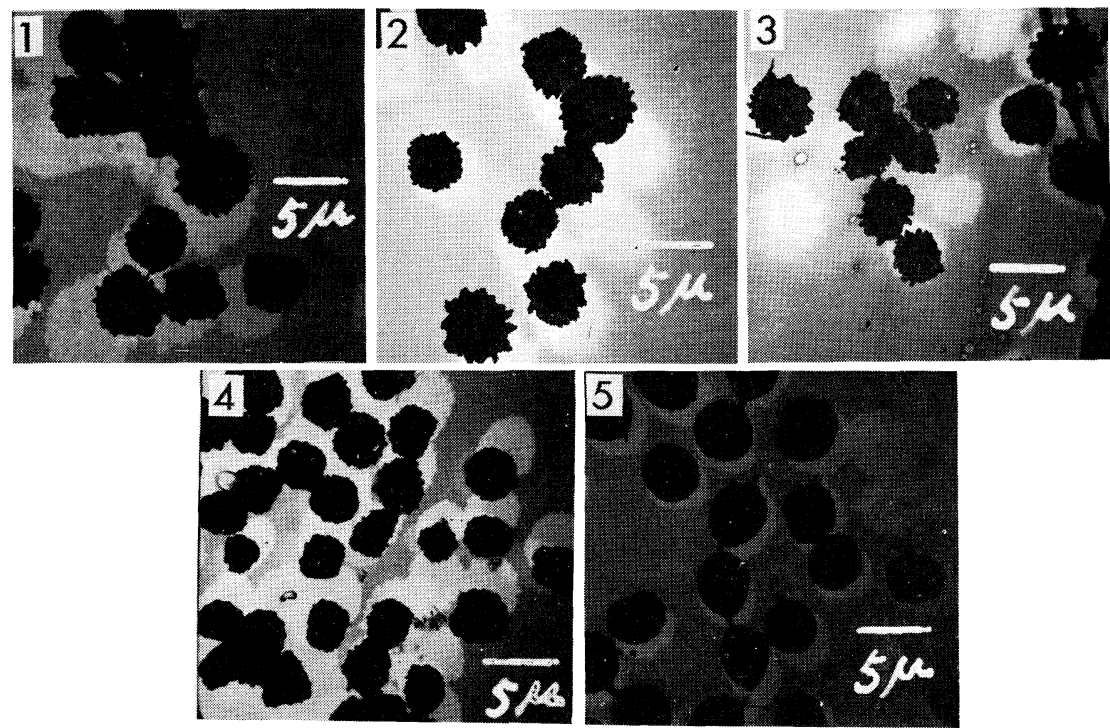

Fig. 3. Electron micrograms of conidia of various strains.
1. Strain ATCC-15517
2. A. parasiticus IAM-2150
3. A. soyae IAM-2669
4. A. flavus OUT-5004
5. A. oryzae OUT-1059

name chosen as descriptive of the vesicular form.

\section{Physiology}

Lethal temperature of strains was compared with each other by culturing dry-heat shocked conidia in test tubes, which were obtained from ricekoji extract agar slants incubated at $30^{\circ}$ for 7 to 10 days. This strain was weakly resistant to the heating like to many strains belonging to $A$. parasiticus or $A$. soyae, and died out on being heated at $80^{\circ}$ for $120 \mathrm{~min}$, at $90^{\circ}$ for $30 \mathrm{~min}$, or at $100^{\circ}$ for 10 to $20 \mathrm{~min}$. On the contrary, majority of the strains belonging to $A$. flavus and $A$. oryzae were more resistant to the heating and barely died out on being heated at about $100^{\circ}$ for 60 to $90 \mathrm{~min}$ (see Table 1).

Acid productivities are well known characters of Aspergilli (10). Surface culture of each strain on $50 \mathrm{ml}$ of Ballg. 10 rice koji extract in $100-\mathrm{ml}$ Erlenmyer flask was carried out for 20 days at $30^{\circ}$, and total acid was determined in its filtrates. Acid productivities shown by titers of $0.1 \mathrm{~N}$ $\mathrm{NaOH}$ per $10 \mathrm{ml}$ of filtrate are given in Table 2 . From this point it seems that this fungus is rather akin to A. parasiticus than to A. flavus and 
Table 1. Thermal death time of conidia of yellow green Aspergilli.

\begin{tabular}{|c|c|c|}
\hline Strains $^{a}$ & $\begin{array}{c}\text { Period of heating } \\
\text { at } 100^{\circ} \\
(\mathrm{min})\end{array}$ & $\begin{array}{c}\text { No. of strains killed } \\
\text { by heating }\end{array}$ \\
\hline \multirow{2}{*}{ A. flavus (12) } & 60 & 10 \\
\hline & 90 & 2 \\
\hline \multirow{3}{*}{ A. parasiticus (24) } & $40<$ & 9 \\
\hline & 60 & 10 \\
\hline & $90>$ & 5 \\
\hline A. soyae (3) & $40<$ & 3 \\
\hline ATCC-15517 (1) & 20 & 1 \\
\hline
\end{tabular}

a Numbers in parentheses represent number of strains examined.

Table 2. Productivity of acid by yellow green Aspergilli cultured on the kojiextract. Acidity is expressed by $\mathrm{ml}$ of $0.1 \mathrm{~N} \mathrm{NaOH} / 10 \mathrm{ml}$ of filtrate.

\begin{tabular}{c|c|c|c}
\hline \multicolumn{2}{c|}{ A. flavus and A. oryzae group } & \multicolumn{2}{|c}{ A. parasiticus and A. soyae group } \\
\cline { 1 - 2 } Strain No. & Acidity & Strain No. & Acidity \\
\hline 23 & 0.50 & 328 & 1.90 \\
40 & 2.00 & 401 & 1.40 \\
65 & 1.80 & 1011 & 2.70 \\
81 & 2.00 & 1023 & 2.00 \\
128 & 1.90 & $1042^{b}$ & 4.50 \\
210 & 1.50 & $1044^{b}$ & 1.90 \\
301 & 1.60 & $1045^{b}$ & 5.30 \\
513 & 3.00 & 1040 & 2.15 \\
606 & 0.80 & 1041 & 3.60 \\
1020 & 1.60 & 1043 & 1.95 \\
1027 & 0.80 & 1046 & 3.80 \\
1029 & 1.41 & 1048 & 0.50 \\
$307^{a}$ & 2.40 & 1049 & 5.20 \\
$315^{a}$ & 1.20 & 1050 & 1.45 \\
$331^{a}$ & 1.10 & 1051 & 10.70 \\
$433^{a}$ & 0.90 & 1053 & 1.90 \\
$505^{a}$ & 0.60 & 1054 & 1.60 \\
$609^{a}$ & 1.40 & 1058 & 1.20 \\
$1028^{a}$ & 0.70 & ATCC-15517 & 10.50 \\
$1030^{a}$ & 1.00 & & \\
\hline
\end{tabular}

a A. flavus group $\quad{ }^{b}$ A. soyae group 
Table 3. Composition of acids produced by yellow green Aspergilli shaken cultured in synthetic medium. Amounts of acids produced are expressed by $\mu$ moles/liter.

\begin{tabular}{|c|c|c|c|c|c|c|c|}
\hline $\begin{array}{l}\text { No. of } \\
\text { strain }\end{array}$ & $\begin{array}{l}\text { Kojic } \\
\text { acid }\end{array}$ & $\begin{array}{l}\text { Lactic } \\
\text { acid }\end{array}$ & $\begin{array}{l}\text { Hydroxy- } \\
\text { glutaric } \\
\text { acid }\end{array}$ & $\begin{array}{l}\text { Succinic } \\
\text { acid }\end{array}$ & $\begin{array}{l}\text { Malic } \\
\text { acid }\end{array}$ & $\begin{array}{c}\text { Citrmalic } \\
\text { acid }\end{array}$ & $\begin{array}{l}\text { Citric } \\
\text { acid }\end{array}$ \\
\hline 69 & mI & -- & 0.06 & 0.65 & 0.34 & + & 0.15 \\
\hline 124 & -- & + & 0.01 & 0.63 & 0.74 & - & 0.08 \\
\hline 127 & - & - & + & 0.23 & 0.63 & - & 0.14 \\
\hline 219 & - & 0.05 & 0.05 & 0.44 & 0.53 & + & 0.18 \\
\hline 315 & $H$ & - & + & 0.66 & 2.06 & - & 0.13 \\
\hline 326 & - & - & + & 0.11 & 0.02 & - & 0.24 \\
\hline 330 & $H$ & - & 0.02 & 0.53 & 1.22 & - & 0.26 \\
\hline 411 & m & - & - & 0.28 & 0.28 & - & - \\
\hline 433 & HI & - & 0.01 & 1.34 & 2.34 & - & 0.14 \\
\hline 532 & H & - & 0.03 & 1.56 & 0.19 & - & 0.09 \\
\hline $405^{a}$ & HIt & - & + & 0.31 & 0.03 & - & 0.06 \\
\hline $1011^{a}$ & \pm & + & + & 1.65 & 0.29 & $H$ & 0.05 \\
\hline $1042^{a}$ & m & + & + & 3.56 & 0.79 & - & 0.17 \\
\hline $1045^{a}$ & m & H & 0.01 & 1.01 & 2.73 & + & 0.14 \\
\hline $1047^{a}$ & mt & - & - & 1.61 & 0.91 & - & 0.04 \\
\hline $1049^{a}$ & WI & - & - & 1.84 & 0.62 & + & 0.03 \\
\hline $1050^{a}$ & H & + & + & 2.87 & 1.12 & - & 0.08 \\
\hline $1051^{a}$ & - & + & - & 2.69 & 0.88 & - & 0.04 \\
\hline $\begin{array}{l}\text { ATCC- } \\
15517^{a}\end{array}$ & HW & - & - & 0.12 & 0.22 & + & 5.64 \\
\hline
\end{tabular}

${ }^{a}$ Strains with remarkably rough-walled conidia.

A. oryzae. By gas chromatographic determination of the medium, main component of acid in this fungus was proved to be citric acid, but succinic acid was found in other fungi, as shown in Table 3.

The predominantly abundant production of blue fluorescence followed by the production of reddish brown pigments is one of the most striking characters of this fungus, but its very weak and sometimes almost lacking amylase activities among many members of yellow green-spored Aspergilli, as shown in Table 4, are enough to make this strain an useless fungus in food-making industries. The enzyme activities of fungi in this table were estimated by the two methods reported previously (11). The one is a method using extracts of several small pieces pierced from the center of the Czapek solution-agar plate with a cork borer, in which was cultured a giant colony of the strain by incubation for 5 to 7 days at $34^{\circ}$, and the other is a method using the extract of soy-sauce koji made with a mixture of wheat and soy- 
Table 4. Amylolytic and proteolytic activities of yellow green Aspergilli.

\begin{tabular}{|c|c|c|c|c|c|}
\hline & \multirow[b]{2}{*}{$\begin{array}{l}\text { Strain no. and } \\
\text { group }\end{array}$} & \multicolumn{2}{|c|}{ Colonial spot } & \multicolumn{2}{|c|}{ Soy-sauce koji } \\
\hline & & $\begin{array}{c}\text { Amylase } \\
D_{30^{\prime}}^{40^{\circ}}\end{array}$ & $\begin{array}{c}\text { Protease } \\
\text { E }\end{array}$ & $\begin{array}{c}\text { Amylase } \\
\mathrm{D}_{30^{\prime}}^{40^{\circ}}\end{array}$ & $\begin{array}{c}\text { Protease } \\
\text { E }\end{array}$ \\
\hline 67 & \multirow{7}{*}{$\begin{array}{l}\text { A. oryzae and } \\
\text { A. flavus }\end{array}$} & HI & \# & 302 & 3.00 \\
\hline 81 & & HWH & mI & 684 & 2.50 \\
\hline 83 & & 㖄 & HI & 499 & 4.80 \\
\hline 127 & & Hell & $H$ & 509 & 2.60 \\
\hline 216 & & HW & + & 415 & 0.05 \\
\hline 333 & & HAt & $H$ & 434 & 1.35 \\
\hline 609 & & H⿻川t & + & 571 & 0.70 \\
\hline 328 & \multirow{19}{*}{$\begin{array}{l}\text { A. parasiticus } \\
\text { group }\end{array}$} & $H$ & + & 32 & 1.98 \\
\hline 401 & & $H$ & \# & 32 & 3.35 \\
\hline 405 & & $H$ & W & 52 & 2.25 \\
\hline 410 & & $H$ & $H$ & 23 & 1.68 \\
\hline 1011 & & $H$ & $H$ & 63 & 1.36 \\
\hline 1023 & & $H$ & W & 76 & 2.90 \\
\hline 1024 & & + & WI & 13 & 1.80 \\
\hline 1040 & & $H$ & $H$ & 82 & 1.15 \\
\hline 1041 & & + & - & 66 & 1.35 \\
\hline 1043 & & + & + & 61 & 1.96 \\
\hline 1046 & & $H$ & + & 91 & 3.30 \\
\hline 1047 & & H & m & 82 & 2.20 \\
\hline 1048 & & H & + & 221 & 0.55 \\
\hline 1049 & & + & $H$ & 47 & 1.58 \\
\hline 1050 & & + & - & 47 & 1.08 \\
\hline 1051 & & $H$ & WI & 85 & 1.65 \\
\hline 1052 & & + & m & 60 & 1.55 \\
\hline 1053 & & $H$ & $H$ & 79 & 3.30 \\
\hline 1054 & & + & + & 58 & 4.40 \\
\hline 1042 & \multirow{3}{*}{ A. soyae } & H & + & 74 & 3.40 \\
\hline 1044 & & + & H & 66 & 3.90 \\
\hline 1045 & & H & HI & 71 & 1.40 \\
\hline ATCC & -15517 & + & m & 50 & 2.75 \\
\hline
\end{tabular}

beans. The amylolytic and proteolytic activities measured by these methods were shown respectively by $\mathrm{D}_{30^{\prime}}^{40^{\circ}}$ (Wohlgemuth value) and by $\mathrm{E}$ (extinction at $660 \mathrm{~m} \mu$ in solution in which the enzyme was acted on casein).

It is very interesting that the $A$. soyae strains, which have been used 
for soy-sauce making in Japan, have smooth conidiophores but prominently roughened conidia and very strong protease activities, while $A$. parasiticus strains, which have rarely been used for that, have both prominently roughened conidiophores and conidia, and their protease activities are not stronger than those of $A$. soyae or A. oryzae and A. flavus.

Several physiological characters of this fungus were compared with those of other fungi by the previously reported method (12-14), in which strain ATCC-15517 was denoted as no. 1055. The activity of this fungus was positive in reducing Methylen Blue or Triphenyltetrazolium chloride but almost negative in coloring phenols such as hydroquinone or pyrogallol, and browning of rice-koji made by this fungus by air scarcely occurred. However, these properties cannot be taken as specific to this fungus, because these characters vary from strain to strain, and sometimes with conditions of experiments.

\section{Mutation}

Mycological relations between this fungus and other fungi were considered by comparing the mutants derived from this fungus with other fungi, and by testing variation in the aflatoxin-producing ability among the mutants. A certain number of conidia of this strain was rubbed and scattered on the surface of Czapek solution-agar plate, then exposed to ultraviolet rays of $2,537 \AA$ emitted from 15 -w UV-lamp, keeping various direct distances from the medium and various hours of exposure, cultured for several days, and 5 kinds of mutants, named B, D, E, G, and I, were obtained. Microstructure and its explanation in addition to exposure condition are shown in Fig. 4 and Table 5, respectively. Strain ATCC-15517, namely, the parent strain, resisted ultraviolet rays more strongly than other fungi. For example, the former survived even after 8 to $10 \mathrm{~min}$ exposure without any variation, but the latter died out or gave rise to a mutant after 4 to

Table 5. Conditions for exposure to ultraviolet irradiation and characteristics of mutants derived from A. parasiticus ATCC-15517.

\begin{tabular}{|c|c|c|c|c|}
\hline \multirow{2}{*}{ Mutant strain } & \multicolumn{2}{|c|}{$\begin{array}{l}\text { Condition of } \\
\text { UV irradiation }\end{array}$} & \multirow{2}{*}{$\begin{array}{l}\text { Type of } \\
\text { mutant }\end{array}$} & \multirow{2}{*}{ Arrangement of sterigmata } \\
\hline & $\begin{array}{l}\text { distance } \\
(\mathrm{cm})\end{array}$ & $\begin{array}{l}\text { time } \\
(\min )\end{array}$ & & \\
\hline B & 30 & 8 & albino & $\begin{array}{l}80 \% \text { in one series, } \\
20 \% \text { in two series }\end{array}$ \\
\hline $\mathrm{D}$ & 30 & 15 & yellow green & $80 \%$ to $100 \%$ in two series \\
\hline $\mathrm{E}$ & 30 & 15 & pigment less & $\begin{array}{l}90 \% \text { in elongation, } \\
10 \% \text { in one series }\end{array}$ \\
\hline G & 30 & 15 & yellow brown & all elongated and enlarged \\
\hline I & 30 & 13 & restricted & 80 to $90 \%$ in two series \\
\hline
\end{tabular}




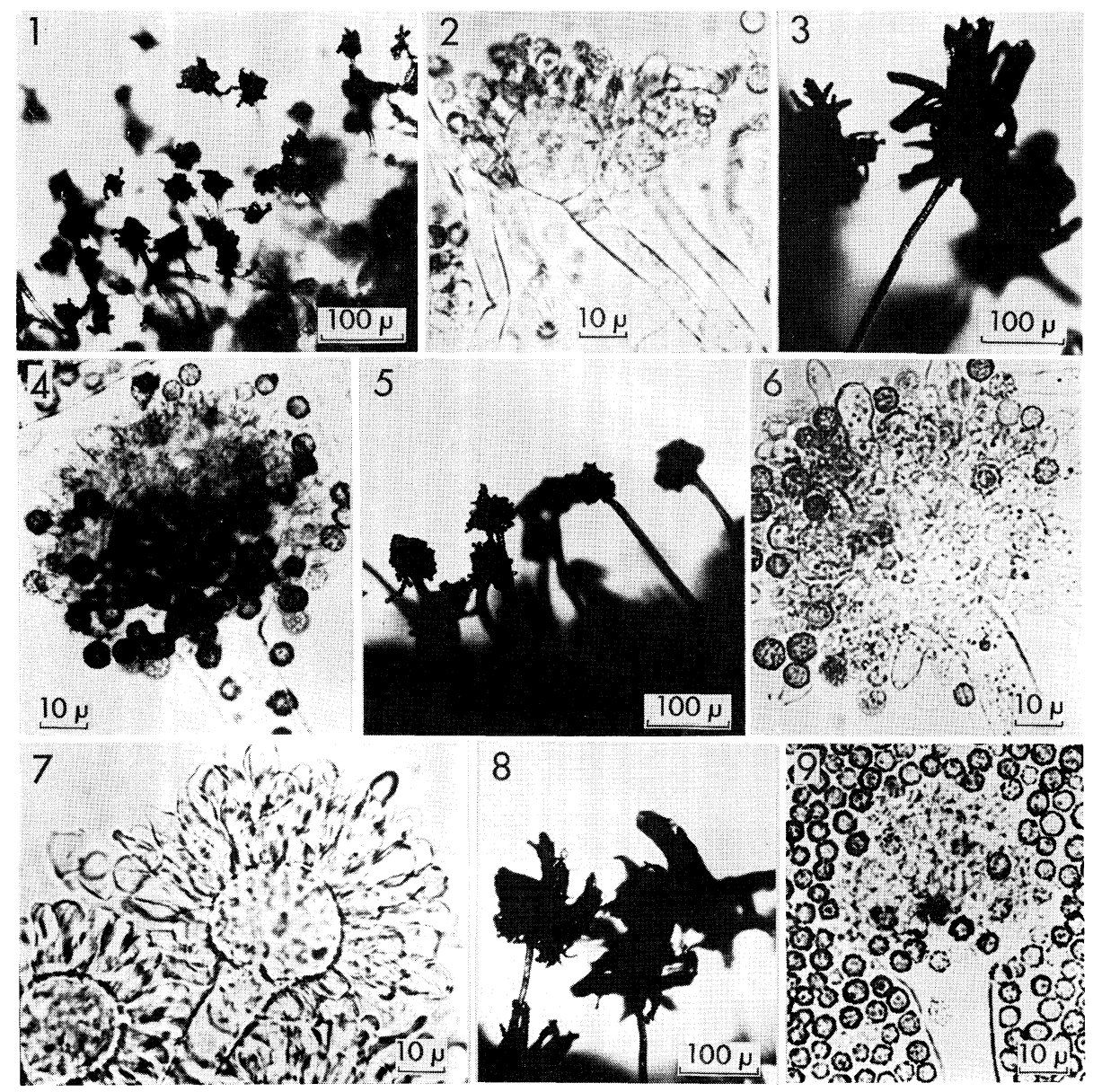

Fig. 4. Microstructure of the mutants B, D, E, G and I, all derived from the strain ATCC-15517.

1. Mutant $\mathrm{B}$, conidial heads are very small.

2. Mutant B, vesicles are small but globose form similar to those of the parent.

3. Mutant D, conidial heads are the same as those of the parent.

4. Mutant D, vesicles are the same as those of the parent.

5. Mutant E, conidial heads are small and their forms are different from the parent.

6. Mutant E, vesicle with elongated sterigmata in two series is seen.

7. Mutant $G$, vesicles with elongated and enlarged sterigmata in two series are seen.

8. Mutant I, conidial heads are the same as those of the parent.

9. Mutant I, vesicle is the same as that of the parent. 
Table 6. Detection and determination by thin-layer chromatography and fluorophotometry of aflatoxin produced by the strain ATCC-15517 and its mutants.

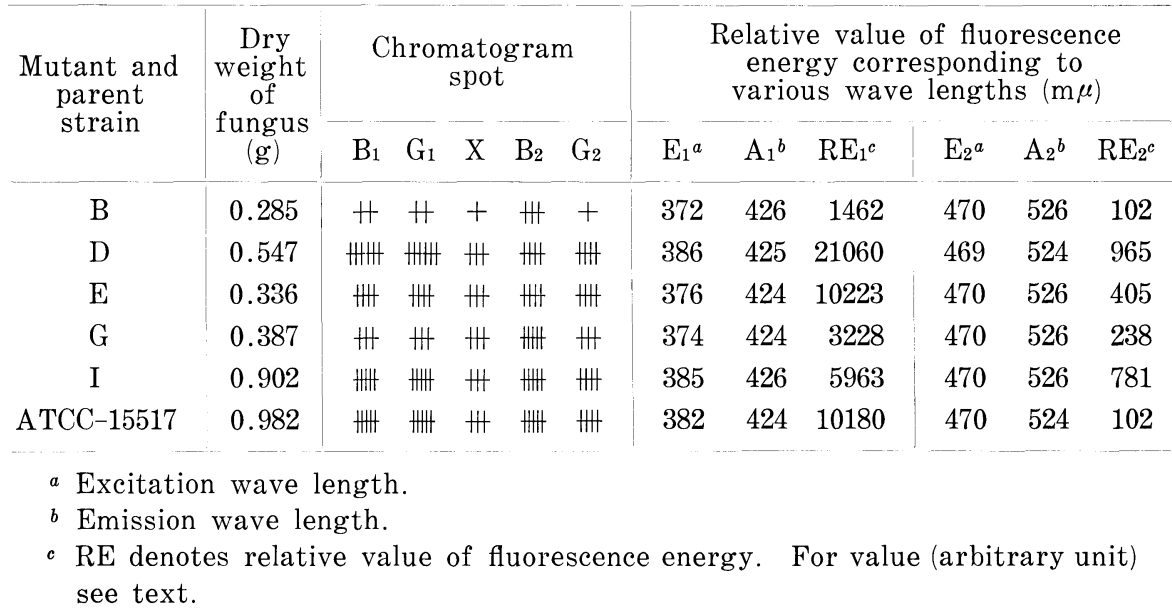

6 min exposure, both at an equal distance of $30 \mathrm{~cm}$ from the medium.

It was observed that mutants varied especially in the arrangement followed by deformation of sterigmata, and sometimes conidial heads were dwarfed, but no variation occurred in wrinkles at colonial reverse, globose shape of vesicles, and roughness of conidiophores and conidia. Therefore, no continuous relations were found among strain ATCC-15517 and other various kinds of strains, at least morphologically, and an independent position of this strain should be supported.

Aflatoxin-producing abilities were compared among these mutants and their parent strain. Strains were cultured in $80 \mathrm{ml}$ of medium (1) by shaking at $30^{\circ}$ for $76 \mathrm{hr}$, and aflatoxin mixture was obtained from the culture filtrate by repeated treatment with chloroform and petroleum ether followed by dissolution in chloroform. Aflatoxin was detected by thin-layer chromatography and determined by spectrofluorophotometer. Total mass of fungi was weighed as dry matter. Results are shown in Table 6, in which signs from + to $\mathrm{mll}$ show the fluorescence intensities of the spots corresponding to their concentrations from weak to strong in that order. Normal components of aflatoxin $B_{1}, G_{1}, B_{2}$, and $G_{2}$ are listed, but $X$ is an unknown, blue fluorescent spot found additionally, in which mutants $\mathrm{D}, \mathrm{E}$, and $\mathrm{G}$ show some brown shaded fluorescence. $\mathrm{E}$ and $\mathrm{A}$ in the table respectively indicate the excitation wave-length and emission wave-length. The relative value of fluorescence energy indicated by $\mathrm{RE}_{1}$ and $\mathrm{RE}_{2}$ were comparatively determined from the value of 2,000 shown by $1 \mathrm{ppm}$ of quinine sulfate solution and that of 1,500 shown by $1 \mathrm{ppm}$ of riboflavin solution, respectively, and both were 
calculated per one gram of dry matter of fungus. Usually, $\mathrm{RE}_{1}$ and $\mathrm{RE}_{2}$ respectively show the concentration of blue and green fluorescent substances contained.

The blue fluorescence decreased except for mutant $D$, in which it increased about two-fold, and the green fluorescence increased in every mutant. From this point of view, strain ATCC-15517 is one of the ordinary yellow green-spored Aspergilli whose blue fluorescence productivity is specially enhanced.

\section{SUMMARY}

In an attempt to clarify the taxonomic situation of the strain ATCC15517, which is a well-known aflatoxin producing fungus, its general morphological and physiological characters, in addition to mutation by ultraviolet rays, were examined by comparing with many kinds of industrial strains used in Japan.

From the results obtained, it seems that this fungus belongs to $A$. parasiticus rather than to $A$. flavus because of its remarkably rough walled conidia and conidiophores, sensitivity to heating, high productivity of acid, strong resistance to ultraviolet light, and other physiological observations, excluding its unstable arrangement of sterigmata.

Thus, it should be placed in a new strain of $A$. parasiticus series by its globose-shaped vesicles: $A$. parasiticus Speare var. globosus MuRAKAMI nov. var.

Finally, it was confirmed that neither this fungus nor its allied strain was found at all in Japanese industrial strains, from the point of morphology.

This work was carried out as a continuation of taxonomic researches on Aspergilli, which has been done by the authors since 1960. The authors wish to thank Emeritus Prof. Dr. K. Sakaguchi and Prof. Dr. H. Iizuka, University of Tokyo, and Dr. M. Suzuki, the director of Research Institute of Brewing, for their continued interest and encouragement.

Series of cultures have been received from many "tané-koji” makers and laboratories in Japan. Dr. K. Miyaki and Dr. K. Aibara, National Institute of Health, Tokyo, gave us their strain of ATCC-15517, which was obtained from Massachusetts Institute of Technology, U. S. A., and made many valuable comments. Dr. R. D. Goos, curator of fungi, American Type Culture Collection, has given informations on this strain. The authors are grateful to their kindness, and also acknowledge the cooperation of the following members of Research Institute of Brewing: Messrs. Y. Ikeda and S. Hyôtô for the cultural and photographic experiments, Messrs. K. Kuwahara and M. Tadenuma for gas chromatographic and spectrofluorophotometric analysis, and Miss. C. Iwata for electron-microscopy. The authors also wish to thank Japan Sake Brewers' Central Association, Tokyo, which supplied facilities for making spectro- fluorophotometric analysis. 


\section{REFERENCES}

1) J. Adye and R.I. Mateles: Biochim. Biophys. Acta, 86, 418 (1964).

2) K. Sargeant, A. Sheridan, J.O' Kelly and R.B.A. Carnaghan: Nature, 192, 1096 (1961).

3) K. Sakaguchi, H. Imzuka and J. Окамото: J. Agr. Chem. Soc. Japan, 25, 79 (1951).

4) C. Thом and M.B. Church: The Aspergilli, The Williams \& Wilkins Company, Baltimore (1926).

5) C. Thom and K.B. Raper: A Manual of the Aspergilli, The Williams \& Wilkins Company, Baltimore (1945).

6) K.B. RAPER and D.I. Fennell: The Genus Aspergillus, The Williams \& Wilkins Company, Baltimore (1965).

7) K. Sakaguchi and K. Yamada: J. Agr. Chem. Soc. Japan, 20, 65, 141 (1944).

8) I. Ohara: J. Agr. Chem. Soc. Japan, 26, 547 (1952).

9) T. Nehira: J. Ferm. Technol. Japan, 35, 50 (1957).

10) K. Sakaguchi: J. Agr. Chem. Soc. Japan, 4, 129, 203 (1928); 6, 400 (1930); 7, $748(1931) ; 8$ 8, 264, 433, 531 (1932).

11) H. Murakami, A. Suzuki, K. Ôwaki and S. Noda: J. Soc. Brew. Japan, 59, 74, $92(1964)$.

12) H. Murakami, A. Suzuki, M. Naganawa and K. Ôwaki: Rept. Res. Inst. Brew. Japan, 137, 1 (1965).

13) H. Murakami, A. Suzuki, K. Ôwaki and K. Kuwabara: Rept. Res. Inst. Brew. Japan, 137, 12 (1965).

14) H. Murakami, Y. Ikeda, S. Hyoto, T. Ishil and K. Kuwabara: Rept. Res. Inst. Brew. Japan, 137, 19 (1965). 